\title{
The School of Public Health at the University of Chile: Origins, Evolution, and Perspectives
}

\author{
Paulina Pino, MPH, PhD, ${ }^{1}$ \\ Giorgio Solimano, $\mathrm{MD}^{2}$
}

\begin{abstract}
With the support of and in accordance with the model of the Rockefeller Foundation, the School of Public Health of the University of Chile was established in 1943 as a training center for public health institution administrators. From the beginning its academic leaders also took the lead in the country's health institutions, allowing the increasing knowledge of public health to be brought directly into practice concurrently with training. The military coup of 1973 halted this cycle and broke and destroyed the links between the school and national governance and policymaking; despite this, the university continued to consolidate its role as the major training institution for public health professionals. During that time the Master's Programs in Public Health and in Biostatistics were launched, attracting students throughout the country and Latin America, but very few professors had adequate research training. Only in 2000, a decade after the return to democracy, a strategic plan was implemented to renew the School of Public Health (SPH) and reshape it for the new public health scenario in Chile. Since then efforts have been made to bring research skills up to date through $\mathrm{PhD}$ training and sending young professors to study abroad. Also, a $\mathrm{PhD}$ program was created in the $\mathrm{SPH}$ in 2003, and graduates are being rapidly hired in universities and the Health Ministry. The recovery of at least part of a leading role of the public health agenda should be based on the capacity to generate relevant new knowledge and advocate for its implementation.
\end{abstract}

Key Words: School of public health, Latin America, Chile, Military Coup of 1973

Recommended Citation: Pino P, Solimano G. The School of Public Health at the University of Chile: Origins, Evolution, and Perspectives. Public Health Reviews. 2011;33:315-22.

\footnotetext{
${ }^{1}$ Associate Professor, Director PhD Program, School of Public Health, Faculty of Medicine, Universidad de Chile.

${ }^{2}$ Full professor, Former Director School of Public Health, Faculty of Medicine, Universidad de Chile.
}

Corresponding Author Contact Information: Paulina Pino at ppino@med.uchile.cl; Independencia 939, Area code 838 0453, Santiago, Chile. 


\section{ORIGINS}

Between the end of the $19^{\text {th }}$ century and the first quarter of the $20^{\text {th }}$ - the Chilean public health system was born under great political turmoil. ${ }^{1}$ The situation was desperate: infection, malnutrition, and high rates of maternal and child mortality were decimating the population, which lived in overcrowded and unsanitary conditions. Physicians would demand, and eventually obtain, decision-making power based on "science and technique". ${ }^{2}$ Training was an emergent necessity, however, as physicians had no administrative skills.

This set the stage for creating a School of Public Health (SPH) in Chile. The actors involved were the Bacteriological Institute, the Faculty of Medicine of the University of Chile* and the Rockefeller Foundation, then in the process of expanding its successful Public Health Schools model. ${ }^{3}$ Thus, in 1943, the SPH was created within the Faculty of Medicine., Unlike the development of similar schools in the United States, there was little discussion of public health as a discipline distinct from medicine. ${ }^{6}$ While the political climate favoured the recognition of the social causes of disease, public health remained a medical speciality and an attractive career option for physicians.

Starting with its foundation, it is possible to distinguish four periods in the development of the SPH, mainly influenced by the national and university context.

\section{Foundation (1943-1959)}

The University of Chile (UCH) SPH established in 1943 was based on the second model of the Welsh-Rose report, i.e., oriented towards training administrators and technical staff for the public health system. ${ }^{6}$ In this model, research would always be a secondary task, carried out only "as long as the teaching duties would allow it". ${ }^{7}$ However, some important applied research was performed. ${ }^{5}$ Training programs did not award degrees, but were organized into a comprehensive course of studies (Main Course) that included all the disciplines found in the US model. The professors, thanks to funding included in the Rockefeller Foundation grant, would be trained at Johns Hopkins and Harvard Universities. ${ }^{8}$

During the foundation period, the SPH had a close relationship with the Faculty of Medicine, as well as with national public health institutions and international organizations, which would continue into the next

\footnotetext{
*At that time called Faculty of Biology and Medical Sciences.
} 
consolidation period. ${ }^{9}$ Directors of SPH, faculty and graduates would be found in the highest levels of management, including leadership positions at the Pan American Health Organization (PAHO), the National Health Service, and the School of Medicine. ${ }^{10}$ This assured academic influence on important decisions in health policy and permitted feedback to the SPH. The increasing success of the policies gave prestige to the new institution.

\section{Consolidation (1960-1973)}

In the consolidation period, the Main Course was replaced by a degree program, reflecting calls for more than training health administrators. ${ }^{11}$ An increasing number of specialty courses were offered to different audiences and in varying degrees of complexity. ${ }^{12,13}$ In a country experiencing major social and political changes, the SPH attracted students throughout Latin America, some of whom would later become important leaders in their own countries.

Lines of research were established and consolidated. Those on maternal and child health and on mortality were especially remarkable for their international impact. ${ }^{14-16}$ Collaboration with the Bacteriological Institute resulted in research on infectious diseases; also the first studies on nutrition appeared, a field that would be greatly developed later on. ${ }^{17,18}$ Nevertheless, by the end of the consolidation period and as a consequence of a university reform, bacteriology and nutrition would become independent departments, a decision that may have inhibited the development of epidemiological research in those areas within the SPH. Also, consequently, the school did not participate in major studies or interventions developed later, such as food supplementation with iron and folic acid, among other important programs.

A significant training experience was the Latin American Maternal \& Child Health Seminar, which was sponsored by PAHO from 1968 to 1997 and graduated 750 students, mostly foreigners. This allowed the successful Chilean experience in maternal and infant health to be transmitted throughout Latin America.

The emergence of interdisciplinary thinking can be perceived: technical areas were established with a strong team in biostatistics, vital statistics, and demography, as well as a sanitation engineering unit. On the other hand, there was recognition of the social sciences, which supported the development of social medicine and participatory community action..$^{19}$ This was closely linked to leftist political movements of the time, similar to experiences in other Latin American countries. ${ }^{20}$ 
The military coup of 1973 had a brutal impact on the development of the school, although the preceding political polarization had precluded constructive academic dialogue. Beyond its impact on academic freedom and the development of participatory public health, the fall of the Chilean democracy implied direct military intervention, political persecution, and forced dismissals, leaving deep wounds and forcing the SPH to start over. ${ }^{21}$

\section{Enduring the Dictatorship and its Aftermath (1974-1999)}

Evidently, during the dictatorship the SPH lost its historical link with public health decision-making. The military government implemented a radical reform of the health system - in essence, still in place — under a privatization ideology, without any consideration of the once powerful public health principles. $22-24$

The SPH focused on academic subjects, still concentrating on training. As it was merged with the Department of Preventive Medicine, it had to take over undergraduate teaching, giving much attention to this new challenge. ${ }^{25-27}$

As for graduate training, in 1981 the public health degree program became the first Master's of Public Health, with several areas of concentration, followed by the Master's of Biostatistics in 1983. The latter was developed with the support of the International Clinical Epidemiology Network (INCLEN) - another significant endeavour of the Rockefeller Foundation - which attracted a new generation of national and international students. Research began to take on greater methodological refinement ${ }^{28-30}$; however, it also moved towards clinical research, collaborating with diverse groups of physicians and to some extent, moving away from the population perspective. ${ }^{31-33}$

Whereas the dictatorship ended in 1990, these features remained more or less unchanged until 1999. During that decade, new reforms inspired by the World Bank were implemented in the health system, again without involvement of the $\mathrm{SPH} .^{34}$

\section{Renewal and Modernization (1999-Present)}

At the end of the 1990's, the atmosphere for public universities had hardly improved, particularly for those disciplines linked to social matters. On the other hand, the public health scenario had changed both in epidemiological and political terms. In that context, the SPH urgently needed major changes. A strategic development plan was developed, which included updating the academic staff and reforming graduate programs. This included launching the first PhD Program in Public Health in the country in 2003. Such 
developments were aimed at creating the internal conditions necessary to promote public health research within the school and to expand it nationwide.

Currently the SPH has 57 professors. Throughout the decade, the number of professors with $\mathrm{PhDs}$ increased from five to 20, and is planned to reach 34 by 2014, as those who are currently enrolled in doctoral training programs, in Chile or abroad, graduate. It is hoped that by 2020 all professors will have doctoral training. The impact of this process is already being noticed through some of the publications of young researchers..$^{35-38}$

The creation of the doctoral program allowed the SPH to obtain national funding, which made it possible to award scholarships for $\mathrm{PhD}$ training or study abroad for faculty members. A key feature has been the possibility of having international professors teach and participate in thesis advising and evaluation. Since 2003, 53 students (six of them foreigners) have joined the program, 16 have passed the qualifying exam, and 11 have graduated. These graduates are in great demand by universities and public institutions.

The two Master's Programs-Public Health and Biostatistics—continue attracting students throughout the country and to a lesser extent, from Latin America. Starting in 2007, the Master's of Public Health was adapted to better comply with professional training standards. During this decade, 514 students were enrolled in the Public Health program and 75 in the Biostatistics program. Technological improvements have facilitated the participation of international professors and permitted the expansion of training beyond the graduate programs.

Both the $\mathrm{PhD}$ and Master's programs are accredited by the National Commission for Graduate Accreditation (CNA), a process which includes a national peer evaluation and report, and, for the $\mathrm{PhD}$ program, an international peer evaluation. During 2000-2006, in collaboration with PAHO and the Latin American and Caribbean Association of Schools of Public Health (ALAESP), the SPH led an initiative on Quality Improvement of Graduate Degrees in Public Health in Latin American and Caribbean Countries. ${ }^{39}$

Despite changes in the political context, the school has not regained its former influence over the public health system. Once again, an ambitious reform - this time oriented towards diminishing health inequities-was carried out during this period. Despite its increasing financial burden, the curative medical branch of this reform has prevailed over a diseaseprevention perspective. ${ }^{40}$ This not only reflects the diminished strength of pubic health but rather a major societal change-towards a market-oriented thinking - that crosses all the country's public spheres. Overcoming this new reality poses a complex challenge to the SPH. 


\section{PERSPECTIVES}

As the SPH maintains its leadership in training it will continue to influence the public health system through its officers and leaders. In earlier times, direct participation in public health decision-making faded out as governmental institutions evolved asserting their own capabilities. Meanwhile, the school has gained academic identity and has strengthened its international network. This will allow new knowledge generation and policy formation on issues such as: obesity and the related chronic diseases epidemic, the impact of reform on health indicators and disparities, workrelated psychosocial determinants of mental health, and environmental threats to health, among others. Also, this research capacity will permit independent evaluation of public health policies and programs.

Technical assistance to the Ministry of Health is another way that the SPH is influencing programs, like the nationwide expansion of the mental health program at the community level, and the updating of standards and norms to diminish health risks in the workplace. Also, it is envisioned that the SPH will participate in national surveys for monitoring health and related events, as required by the Ministry and other public institutions. For example, the school is participating in the First National Food and Nutrition Survey with the Department of Nutrition. Incidentally, this will also generate alliances as a way of strengthening the future presence of the school in public health matters.

In conclusion, after 68 years the SPH is again in position to take over academic leadership based on its renewed capacity of knowledge production and advanced training, so that it ultimately may influence public health thinking and policy.

Conflicts of Interest: None declared.

\section{REFERENCES}

1. Romero H. Desarrollo de la medicina y la salud pública en Chile. Parte II. Revista Médica de Chile. 1972;100:26.

2. Illanes M. En el nombre del pueblo, del estado y de la ciencia. Santiago: Ministerio de Salud; 2010.

3. Fee E. Disease \& discovery: a history of the Johns Hopkins School of Hygiene and Public Health, 1916-1939. Baltimore and London: The Johns Hopkins University Press; 1987.

4. Goic GA. La escuela de salud pública: 25 años al servicio de la educación médica y la salud. Rev Med Chil. 1994;122:951-4.

5. Hevia P. Los inicios de la escuela de salud pública de Chile: 1943 - 1957. Revista Chilena de Salud Pública. 2006;10:70-7. 
6. Fee E. The Welch-Rose Report: blueprint for public health education in: The Welch-Rose Report: A public health classic, a publication by the Delta Omega Alpha Chapter to mark the 75th anniversary of the founding of the Johns Hopkins University School of Hygiene and Public Health, 1916-1992. Baltimore: Delta Omega Honorary Public Health Society; 1992. p.1-42.

7. Adriasola G, Horwitz A, Viel Vicuna B, Villalobos M, editors. La escuela de salud pública de la Universidad de Chile. Terceras Jornadas de Saludbridad. Santiago, Chile; 1954.

8. Viel B. Ayuda extranjera para el desarrollo de la enseñanza médica y de salud pública en Chile. Rev Med Chil. 1961;89:571-5.

9. Rosselot J. Origen, desarrollo y perspectivas de las instituciones de salud publica en Chile. Rev Med Chil. 1993;121:1075-85.

10. Jimenez de la Jara J. Abraham Horwitz (1910-2000): padre de la salud publica panamericana. Rev Med Chil. 2003;131:929-34.

11. Díaz S. La Escuela de Salubridad de la Universidad de Chile. Santiago: Universidad de Chile; 1957.

12. Geyer JC, Unda Opazo F. Curso de especialistas en salubridad para ingenieros dictado en la Escuela de Salubridad, Facultad de Medicina de la Universidad de Chile. Bol Oficina Sanit Panam. 1956;41:147-51.

13. Behm H, Gutierrez H. Demographic training in schools of public health with special reference to the University of Chile. Milbank Mem Fund Q. 1964; 42:287-98.

14. Viel B. Abortion epidemic in Latin America. Dev Forum. 1983;11:7.

15. Behm H. Needed research on Latin America mortality in relation to public health. Milbank Mem Fund Q. 1965;43:S338-53.

16. Behm H. Recent mortlity trends in Chile. Vital Health Stat 1. 1964:1-34.

17. Arteaga A, Valiente S, Rosales E, Urteaga C. La hipovitaminosis A: un problema nutricional colectivo en Chile. Bol Oficina Sanit Panam. 1969;66:200-10.

18. Canessa I, Valiente S, Jaramillo J, Pantoja A, Garcia De Los Rios M, Mella I. Investigación de la morbilidad diabética en Chile. Rev Med Chil. 1960;88:22-8.

19. Ipinza. Calidad y atención integral de salud: dos conceptos inseparables. Cuadernos Medico Sociales. 2007;47:5-18.

20. Waitzkin H, Iriart C, Estrada A, Lamadrid S. Social medicine then and now: lessons from Latin America. Am J Public Health. 2001;91:1592-601.

21. Medina E. Letter: health services in Chile. Lancet. 1974;2:1006.

22. Manuel A. The Chilean health system: 20 years of reforms. Salud Publica Mex. 2002;44:60-8.

23. Reichard S. Ideology drives health care reforms in Chile. J Public Health Policy. 1996; 17:80-98.

24. Unger JP, De Paepe P, Cantuarias GS, Herrera OA. Chile's neoliberal health reform: an assessment and a critique. PLoS Med. 2008;5:e79.

25. Medina E, Kaempffer AM, Lemesch C, De la Fuente M, Molina R, Soto R. Ensenanza de salud publica en la escuela de medicina. Experiencia en el Area Hospitalaria norte. Rev Med Chil. 1971;99:522-8. 
26. Medina Lois E. Tendencias y situacion actual de la ensenanza de salud publica y medicina preventiva en la carrera de medicina. Rev Med Chil. 1980;108:94555.

27. Belmar R, Fassler C, Heiss G, Lopez H, Lopez J, Weber C, et al. Ensenanza de salud publica y medicina social en el area central. Rev Med Chil. 1971;99:52935.

28. Cumsille F, Pereda C, Legarreta A, Margozzini J, Mascaro J, Botteselle V, et al. Metodo para homogeneizar informacion sobre desnutricion en la ninez. Bol Oficina Sanit Panam. 1985;99:355-61.

29. Medina E, Kaempffer AM, Cumsille F, Medina R. Encuestas de morbilidad y atencion medica como metodo de analisis de situacion de salud. Bol Oficina Sanit Panam. 1987;102:594-605.

30. Medina E, Pascual JP, Cumsille F, Alegria A, Gutierrez L, Corvalan L, et al. Encuesta de tabaquismo en la poblacion general de Santiago. Rev Med Chil. 1986;114:257-62.

31. Defilippi C, Gomez E, Cumsille F. Relationship between small intestinal fasting motility and vomiting in dogs. Dig Dis Sci. 1990;35:406-10.

32. Herrera P, Arias H, Valenzuela C, Galanti M, Rivera G, Prenzel I, et al. Fiebre paratifoidea B en dos areas de Santiago. Un analisis de su significacion epidemiologica. Rev Med Chil. 1990;118:1393-400.

33. Dussaillant GR, Cumsille F, Ramirez A, Pacheco C, Ugalde H, Oyonarte M. La clasificacion de lesiones coronarias de la Society for Cardiac Angiography and Interventions predice mejor el éxito de la angioplastia coronaria que la del American College of Cardiology/American Heart Association. Rev Med Chil. 2001;129:605-10.

34. Solimano G, Vergara M. Salud en la América Latina del siglo XXI: el caso chileno. In: Brachet-Márquez V, editor. Salud Pública y regímenes de pensiones en la era neoliberal Argentina, Brasil, Chile y México 1980 - 2000: El Colegio de México; 2007.

35. Corvalan C, Uauy R, Kain J, Martorell R. Obesity indicators and cardiometabolic status in 4-y-old children. Am J Clin Nutr. 2010;91:166-74.

36. Burgos S, Koifman RJ, Montano Espinoza R, Atria Curi J. Tipologias residenciales en comunidades chilenas en condiciones de precariedad habitacional. Rev PAlonso FT, Garmendia ML, Bogado ME. Increased skin cancer mortality in Chile beyond the effect of ageing: Temporal analysis 1990 to 2005. Acta Derm Venereol. 2010;90:141-6.

37. Garmendia ML, Pereira A, Alvarado ME, Atalah E. Relation between insulin resistance and breast cancer among Chilean women. Ann Epidemiol. 2007; 17:403-9.

38. OPS, ALAESP. La calidad de la enseñanza de la salud pública: Un desafío impostergable. anam Salud Publica. 2011;29:32-40.

39. Valdivieso DV, Montero LJ. El plan AUGE: 2005 al 2009. Rev Med Chil. 2010;138:1040-6. 